Running head: Are collaborative agreements in innovation activities persistent?

\title{
Are collaborative agreements in innovation activities persistent at the firm level? Empirical evidence for the Spanish case
}

Erika Raquel Badillo ${ }^{a^{*}}$

Rosina Moreno ${ }^{\mathrm{a}}$

${ }^{a}$ AQR-IREA Research Group, University of Barcelona, Barcelona, Spain

Department of Econometrics, Statistics and Spanish Economy, University of Barcelona.

Av. Diagonal 690, 08034 Barcelona, Spain. Tel. +34934021823 - Fax +34934021821

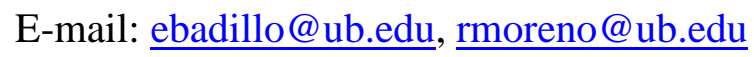

*Corresponding author: ebadillo@ub.edu 


\begin{abstract}
We provide evidence on the dynamics in firms' cooperation behaviour in innovation activities. Our main objective is to analyse if collaborative agreements are persistent at the firm level; and, in such a case, to study what are the main drivers of this phenomenon. We also study to what extent such persistence is different from persistence in $R \& D$, so that the former exists on top of the latter. Finally, we deal with the differentiated persistence pattern of collaboration agreements for different types of partners, as well as the possibility of finding persistence across them. We follow a dynamic approach in the analysis of cooperation persistence: We take into account the unobserved individual heterogeneity and address the initial conditions problem. We use a representative sample of Spanish firms for the period
\end{abstract} 2002-2010.

Keywords: Cooperation in innovation; Innovative Spanish firms; Persistence; Technological partners

JEL classification: L24; O32; D22; C23 


\section{Introduction}

Empirical contributions to the study of cooperation in innovation have expanded significantly in the last decades (Tether, 2002; Miotti and Sachwald, 2003; López, 2008; Abramovsky et al., 2009). However, understanding the persistence with which these agreements are carried out remains an important and under-researched topic. From a management perspective, cooperating in a persistent way allows firms to obtain know-how knowledge, which involves information about who knows what and who knows what to do, as well as the social ability to cooperate and communicate with different partners (Lundvall, 2004).

The main objective of this paper is to analyse if collaborative agreements in innovation are persistent at the firm level; and, in such a case, to study what are the main drivers of this phenomenon. In addition, we assess whether firms cooperate persistently on top of the widely documented persistence that is found in R\&D activities (Peters, 2009; Raymond et al. 2010; Triguero and Córcoles, 2013; Arqué-Castells, 2013; among others). We also aim at providing evidence on the extent to which having participated in technological collaborations with one type of partner in the past influences current collaborative agreements -- not only with the same but also with other type of partners.

Knowing which determinants of persistence are prevalent has important policy implications: If collaboration activities are state dependent, collaboration-stimulating policy measures, such as government support programmes, would be expected to have a deeper effect: They not only affect current collaboration agreements but also are likely to induce a permanent change in favour of cooperation. If, on the contrary, persistence is driven by individual characteristics, temporary shocks to technological collaboration will rapidly dissipate, and support 
programmes are unlikely to have long-lasting effects: In this case, policy should focus more on policies that try to improve the specific factors that drive cooperation in innovation.

We follow a dynamic approach in the analysis of cooperation persistence: We take into account unobserved individual heterogeneity and address the initial conditions problem for a sample of Spanish firms in the period 2002-2010. On average, we find that a firm that cooperates in $\mathrm{t}-1$ has a probability of cooperating in $\mathrm{t}$ that is around 33 percentage points higher than that of a firm that did not cooperate in the previous period. We also show that such persistence is genuine in the sense that it is beyond the persistence that is observed in R\&D. While the highest persistence is found in the case of vertical collaboration, we also observe that cooperation agreements with research-based agents increase the likelihood of cooperating in the future with a different type of partner.

After this introduction, Section 2 proceeds with the literature review. Section 3 describes the database that is used, and Section 4 presents the empirical model. In Section 5 we present and discuss our results; and the main conclusions of the paper are presented in Section 6.

\section{Literature review and hypothesis}

\subsection{Persistence in cooperation in innovation activities}

The degree of cooperation persistence of a firm could be defined as the positive impact of past collaborations on present cooperation agreements. In principle, there are several potential sources for persistent behaviour (Heckman, 1981a). First, it might be caused by true state dependence: The decision to innovate through cooperation in one period in itself enhances the 
probability to cooperate in the subsequent period. Second, firms may have some specific characteristics that make them prone to cooperate. To the extent that these characteristics persist over time, they will inevitably induce persistence in cooperation agreements as well.

Such features can be classified into observable attributes, such as firm size or a firm's absorptive capacity, and unobservable attributes, such as managerial abilities or the stock of tacit knowledge, that are typically not observed. If these unobserved features present correlation over time, and are not properly controlled for in the estimation, past cooperation activities may appear to affect future cooperation simply because it picks up the effect of these persistent unobservable characteristics. This is known in the literature as spurious state dependence. As a consequence, the unobserved individual heterogeneity and the well-known initial conditions problem have to be addressed rigorously.

We can argue in favour of the existence of true state dependence in cooperation activities through various mechanisms and processes. Experience of collaboration has a positive effect on subsequent alliance performance mainly because firms develop and establish routines and procedures that are associated with positive performances and are, therefore, replicated and perpetuated without drastic changes, which leads to path dependency in their behaviour and strategy (Hoang and Rothaermel, 2005; Nieto and Santamaría, 2007). The idea is that successful cooperation projects positively affect the conditions for further cooperation agreements in subsequent years.

In the same vein, cooperation experience should be considered as an incremental learning process. On the one hand, by cooperating firms acquire a set of capabilities and knowledge stocks that allow them to benefit by learning from specific areas of specialisation of their 
partners (Dyer and Singh, 1998; Gulati, 1999; Eisenhardt and Martin, 2000). The ability to leverage the complementary resources of its partners successfully depends on the firm's level of prior-related knowledge, which partly consists of previous experience of collaboration.

This learning is related to the concept of "learning by interacting", which points to how interaction in innovation enhances the relationship with external partners (Lundvall, 1988, 2004; Jensen et al., 2007). Since a firm's ability to recognise the value of new external information as well as to assimilate and apply it to commercial ends is a function of the level of knowledge, learning in one period will allow for a more efficient accumulation of external knowledge in subsequent periods (Cohen and Levinthal, 1990). This cumulative nature of knowledge would induce state dependence in cooperative behaviours.

On the other hand, experience in networking will also have an effect on the management of collaborative agreements. The literature on organizational learning shows that firms that continuously engage in alliances learn from previous experience, as these firms learn how to manage these hybrid organizational forms by repeatedly engaging in them (Levitt and March, 1988; Powell et al., 1996; Nieto and Santamaría, 2007).

In addition, the more alliance experience that a firm has, the more that it becomes structurally embedded in an alliance network, which provides it with network-level information on new partnering opportunities (Granovetter, 1985). It also brings information with respect to a firm's reputation to potential partners, which enhances their ability to assess the firm's attractiveness. In such a scenario a greater degree of trust between firms that cooperate continuously may be reached, which is a basic requisite for a successful partnership (Gulati, 1995; Nooteboom, 2004). 
Another reason why some firms are expected to be persistent cooperators in innovation lies in the fact that cooperation agreements involve costs that may not be recoverable. Firms need to incur start-up costs for establishing cooperation alliances (for instance, costs that are related to searching, training, and adapting to partners) and sometimes require a relatively large initial investment. This kind of costs can be considered, at least partly, as sunk costs (Sutton, 1991; Cohen and Klepper, 1996) and entail barriers to entry into and exit from cooperation projects.

Firms that are involved in innovation alliances should be reluctant to cease cooperating, so as to increase the probability of recovering their initial investments and gain positive results from such agreements. The presence of important sunk costs represents an essential motive for entering and staying in a specific alliance (Le Bas et al., 2011). As is pointed out by Clausen et al. (2012), technological agreements in which knowledge is jointly developed between firms, interactions between customers and suppliers, or cooperation with research institutions may have important sunk costs and may, therefore, be more durable.

While most studies on cooperation strategies in innovation have examined their determinants and the consequences on the firm's performance in a single point in time, the dynamics of such cooperative behaviour has been relatively ignored. From our knowledge, Belderbos et al. (2012) and Jacob et al. (2013) are the only efforts to explore the persistent character of alliance strategies although with very specific objectives. Whereas the first study uses a data set on innovative Dutch firms to analyse the persistence of and interrelation between horizontal and vertical technology alliances, the second study examines to what extent prior engagement in international alliances with partners from developed countries increases the 
propensity to form technology alliances with partners that are based in emerging economies, and vice-versa.

In view of the scarcity of previous evidence on the persistence of cooperation in innovation, and based on the above-mentioned arguments in favour of true state dependence for such activity, we put forward the following hypothesis:

Hypothesis 1: Prior cooperation in innovation activities raises the likelihood of subsequent cooperation.

\subsection{Is persistence in cooperation in innovation genuine or due to persistent $R \& D$ ?}

The issue of persistence in cooperation in innovation is relevant since it determines how systematically firms gain access to external knowledge and innovation resources through the strategy of cooperation with other firms or research institutions. One can think that cooperation persistence in innovation can be related to the traditional issue of whether or not, and to what extent, $R \& D$ is persistent.

Indeed, if firms carry out R\&D persistently because they consider it to be a valuable input for their competitiveness, they are also likely to show persistence in other activities that lead them to engage in innovation. Apart from investing in internal and external $R \& D$, a firm can rely on a combination of different strategies to engage in innovation, such as buying licenses or through cooperative agreements. All of them can be employed to acquire and internalize technological knowledge: the "firm's innovation strategy" (in the words of Veugelers and Cassiman, 1999). 
However, the determinants of the different strategies to innovate can differ from each other. Indeed, some determinants of cooperation in innovation refer to the ability of the firm to capture external knowledge from information sources that are situated in the public domain, which are not among the determinants of carrying out R\&D. As a consequence, if the motivations for cooperation in innovation activities and for carrying out $R \& D$ are partly different, their degree of persistence can also be different.

In addition, some arguments in favour of the persistent nature of cooperation in innovation are specific and different from the arguments for persistence in R\&D. For instance, the drivers that are related to the experience that is gained in managing collaborative agreements and the firm's reputation with potential partners, as well as the "learning by interacting" argument, are specific to persistence in cooperation, whereas they are not directly related to persistent $R \& D$ investments.

In addition, the continuity of a cooperation agreement depends not only on the firm itself, but also on the decision by the counterparty as to whether to continue with such alliance, which can make this category of activities less continuous than are R\&D activities. In addition, cooperation activities are risky not only because all innovation activities are inherently risky but also because partners can take opportunistic behaviours that cannot be anticipated. This can make some cooperative agreements of a shorter duration than $R \& D$ activities that depend exclusively on the firm's own decisions. These arguments form the basis for the next hypothesis: 
Hypothesis 2: Persistence in cooperation in innovation is expected to be different from persistence in $R \& D$.

\subsection{Persistence with different types of cooperative partners and across them}

Different forms of cooperation may exhibit different degrees of persistence, depending on the resource deficiency of the firm. Firms may consider the specialised resources and capabilities that are owned by suppliers and customers, competitors, and research institutions and how they may differentially contribute in providing complementarity (Belderbos et al., 2012). And this differential complementarity may imply different time persistence.

On the other hand, because partner types differ in their risk profiles, differences in cooperation persistence may arise. For instance, collaboration with competitors may be less persistent because the fear of helping a rival and the lack of trust may cause this strategy to cease, given the increased risk of opportunistic behaviour (Nieto and Santamaría, 2007). In contrast, cooperation with universities and research institutes allows low-risk access to specialist knowledge so that it would be easier to find long-term strategic research collaboration with such institutions (Archibugi and Coco, 2004; Veugelers and Cassiman, 2005; Arranz and Arroyabe, 2008; Woerter, 2012).

Risks in customer alliances are also relatively limited when compared with competitors and are expected to be outweighed by the strategic value of access to information with respect to specific customer needs and the higher chances of initial market approval and future commercial accomplishment. In this way, customer alliance strategies can exhibit a higher degree of persistence, which could be attributed to the strategic importance of customers as 
collaboration partners through the whole innovation process: early stages to access novel ideas; co-creation; and later phases to gain market acceptance and wider diffusion. All of these arguments lead us to posit the next hypothesis:

Hypothesis 3: Different types of cooperation partnerships have different persistence levels. Specifically, cooperation with competitors is likely to be the least persistent strategy, whereas cooperation with research institutions and vertical cooperation are likely to present the highest persistence.

In addition, the literature on organizational learning discusses how firms that repeatedly cooperate learn how to manage cooperation agreements by repeatedly engaging in them (Levitt and March, 1988). This experience of cooperation activities is not restricted to the fact of cooperating with the same type of partner (i.e., competitors, clients, suppliers, or universities and research centers). Firms with experience in technological cooperation agreements that are gained through long-standing relationships are likely to join other partners, even if they are of a different nature than the previous ones, just because they have learned to develop and establish routines, policies, and procedures that are based on their previous experiences.

Initially, since collaboration with research institutions is seen as an inexpensive and low-risk source of specialist knowledge, which is generally focused on the most basic R\&D, this type of cooperation may provide the basis and tools for forming future agreements with other types of collaboration partner. Certainly, in subsequent stages, the firm may need to initiate cooperation alliances with customers or suppliers to adapt their processes to this new technology. 
By contrast, since the objectives of vertical collaborations often differ from those of horizontal collaborations and there exists the risk of undesirable knowledge spillovers and free-ridership, especially in the case of collaboration with competitors (Ahuja, 2000), these types of agreements would not seem to influence significantly the future decisions to join partners of a different nature. Therefore, we formulate our final hypothesis:

Hypothesis 4: Research collaboration with clients, suppliers, and competitors tends to be most often influenced by the knowledge that is gained through prior collaboration with research institutions.

\section{Dataset, variables and descriptive analysis}

\subsection{Dataset and variables}

We use the Technological Innovation Panel (PITEC) $)^{1}$. The data come from successive waves of the Spanish Innovation Survey that is conducted every year by the Spanish Statistical Institute, which in turn is based on the Community Innovation Survey. Given the specific aim of this study and because the questions about cooperation are asked in a three-year period (i.e., the survey asks whether or not the firm cooperated in the period between $t-2$ and $t$ ), we consider four waves of the PITEC: 2004 (wave 2002-2004); 2006 (wave 2004-2006); 2008 (wave 2006-2008); and 2010 (wave 2008-2010). We thus cover the period 2002-2010.

\footnotetext{
${ }^{1}$ This database is produced jointly by the Spanish National Statistics Institute, the Spanish Foundation for Science and Technology and the Cotec Foundation (http://icono.fecyt.es/PITEC/Paginas/por_que.aspx).
} 
A cleaning process has been carried out, and only those firms that belong to the industrial and service sectors, with at least 10 employees and positive sales have been taken into account. ${ }^{2}$ In addition, since we are interested in the persistence of cooperation in innovation activities, our analysis is restricted to firms that engage in innovative activities for which technology collaboration is relevant. ${ }^{3}$ We distinguish two panel data sets: The first data set is an unbalanced panel that comprises all firms that are present in at least two consecutive waves; the second data set is a balanced sub-sample, so that only firms that are present in all of the waves are included. Table 1 shows some characteristics of the two data sets.

[Insert Table 1 around here]

In each PITEC survey, for a three-year period, the firm is asked if it had any cooperation agreement with other firms or institutions with respect to its innovation activities. Based on this question, we define our dependent variable of cooperation as an indicator variable that takes the value 1 if the firm decided to cooperate and zero otherwise. ${ }^{4}$

\footnotetext{
${ }^{2}$ Firms that report confidentiality issues, mergers, closures and employment incidents are eliminated. Additionally, the influence of extreme values has been treated. In particular, those observations of R\&D intensity for which internal R\&D expenditures are reported to be greater than two times the volume of sales have been replaced with a maximum of 2 . This was the case of 197 observations. In addition, as a robustness check, all observation with a $\mathrm{R} \& \mathrm{D} /$ sales ratio that was greater than 0.5 were excluded and the regressions that are reported below were re-run. The results were basically unchanged. These results are available from the authors upon request.

${ }^{3}$ That is, firms that have introduced innovations in products or processes, or who were undertaking innovation activities during the analysed period or abandoned them.

${ }^{4}$ Note that a lag of this variable refers to a wave lag: two to four years; two lags refer to four to six years, and so on.
} 
PITEC also asks firms with which kind of partner they cooperated in their innovation processes. Consequently, we distinguish between three different types of cooperation agreements in order to analyse to what extent the experience in cooperating with one type of partner influences the probability of cooperating with the same or with other types of partners: Horizontal cooperation (with competitors or other enterprises of the same sector); Vertical cooperation (with suppliers of equipment, materials, components or software or with customers or clients); and Institutional cooperation (with consultants, commercial labs, or private R\&D institutes; universities or other higher education institutions; government or public research institutes; or technological centres). ${ }^{5}$

The explanatory variable of main interest is the lag of the dependent variable. Notice that the dataset prevents us from observing individual collaborative agreements between firms, but rather their general collaboration behaviour. Therefore, persistence is understood as continuously collaborating, irrespective of whether it is with the same firm or different firms in each period.

We also control for other factors that have traditionally been considered in the literature as influencing the decisions to engage in innovation alliances. Not considering them explicitly in the regression analysis would bias the results with respect to the true state dependence in the innovative cooperation strategy. Among the factors that lead firms to engage in collaborative innovative activity, we focus on: incoming spillovers; appropriability conditions; the firm's

\footnotetext{
${ }^{5}$ The survey also offers information on another type of cooperation: cooperation with firms in the same group. However, we do not consider such typology since only firms that belong to a group can cooperate within their group, while all of the other types of partners can be chosen by all firms. However, in order to control for the possible different behaviour of such firms, the regression analysis includes a dummy variable for firms that belong to a group.
} 
absorptive capacity; and the receipt of public funding for innovation. We also control for some firm characteristics, such as firm size, whether the firm belongs to a group of enterprises, and sectoral dummy variables at the 2-digit level according to NACE-93.

Incoming spillovers refer to the flows of external knowledge that a firm is able to capture, and the information sources for them are usually situated in the public domain (Cassiman and Veugelers, 2002). This variable is measured by the importance that the firm attributed, on a four-point scale, to publicly available information for the innovation process of the firm. The information sources were conferences, trade fairs, exhibitions, scientific journals and trade/technical publications, and professional and industry associations. To generate a firmspecific measure of incoming spillovers, we aggregated these answers by summing the scores on each of these questions and then the variable was rescaled from 0 (unimportant) to 1 (crucial). Firms that place a higher value on incoming spillovers and externally generated knowledge in their innovative activity might have a greater scope for learning and gaining from knowledge that is exchanged through cooperative agreements. So these firms are expected to be more likely to be actively engaged in cooperation and to do it more persistently.

Likewise, we account for appropriability conditions: Greater appropriability of the results of innovation through intellectual property (IP) protection may have a positive effect on cooperating persistently in innovation, as firms can control outgoing information flows, and there are reduced incentives for others to become a free rider on other firms' investments (Cassiman and Veugelers, 2002). However, excessive legal protection may hinder the internalization of the flows that are shared by the partners and may thus have a negative effect on cooperation in innovation (Hernán et al., 2003; López, 2008). As a proxy for 
appropriability conditions, we computed the variable legal (IP) protection, which considers whether the firm used at least one legal IP method for protecting inventions or innovations (patents, registered an industrial design, trademark, or copyright), taking a value of 1 if used, and zero otherwise.

Regarding the receipt of public funding for innovation, when firms obtain public $\mathrm{R} \& \mathrm{D}$ subsidies they may be more likely to establish cooperation agreements with other firms or with institutions given that this way they have the resources to do the research (Arranz and Arroyabe, 2008; Busom and Fernández-Ribas, 2008; Abramovsky et al., 2009). Also, many times public support programmes for $R \& D$ activities aim to ease cooperative innovation agreements by firms that would otherwise not engage in such activity. In order to distinguish the effect from different sources of public R\&D subsidies, we define three binary variables: local, national and European funding. This variable takes the value 1 if the firm received public funding from local or regional authorities, central government and European Union, respectively, to carry out its innovation activities, and zero otherwise.

$R \& D$ intensity as a proxy for absorptive capacity and firm size are expected to influence positively cooperation activities. Firms' R\&D intensity (measured as the share of internal R\&D expenditures in total sales) represents their R\&D efforts (experience and knowledge accumulated); and according to Cohen and Levinthal (1989), greater efforts in R\&D increase the firm's capacity to recognise, value, and assimilate external knowledge from cooperation agreements. Absorptive capacity could make them more attractive cooperation partners for other firms and make them being persistent cooperators (Bayona et al., 2001; Fritsch and Lukas, 2001; Miotti and Sachwald, 2003; Hernán et al., 2003; Belderbos et al., 2004; Röller et al., 2007; Arranz and Arroyabe, 2008). 
Further, it is argued that large firms have more resources and certain capabilities to be more able to make the commitments that are required for partnerships and to benefit from cooperation agreements and from economies of scale (Bayona et al., 2001; Fritsch and Lukas, 2001; Tether, 2002; Belderbos et al., 2004). To measure the Size variable, we constructed four categorical variables (<50 employees; 50-249; 250-499; and >500).

We expect a firm that belongs to a group of enterprises to be more likely to engage in cooperation in innovation and to do it in a continuous way. Firms that are part of a group may have access to a substantial pool of resources that make them more attractive as cooperation partners (Ahuja, 2000; Miotti and Sachwald, 2003; Belderbos et al., 2012). We define a binary variable that takes the value 1 if the firm belongs to a group of companies, and zero otherwise. See Table A1 in the Appendix for a more detailed explanation of the definitions of the variables. To reduce problems of simultaneity with the decision of engaging in innovation cooperative agreements, all of the independent variables are one-wave lagged.

\subsection{Descriptive analysis}

Some descriptive statistics of the variables that are used in our empirical analysis are shown in Table 2. Although all of them can vary across firms and time, we can see that in all cases the variation across firms ("between" variation) is much higher than the time variation ("within" variation).

[Insert Table 2 around here] 
Table 3 reports the transition probabilities of engaging in cooperation agreements in innovation between periods $\mathrm{t}-1$ and $\mathrm{t}, \mathrm{t}-2$ and $\mathrm{t}$, and $\mathrm{t}-3$ and $\mathrm{t}$. In the unbalanced panel, nearly $71 \%$ of the cooperators in one wave persisted in cooperation in the subsequent wave (after two to four years), while $29 \%$ stopped their alliances. In a similar vein, about $84 \%$ of the noncooperators remained in this status in the following wave, and $16 \%$ changed into agreements of cooperation in the subsequent period. The corresponding figures are very similar for the balanced panel. Therefore, the probability of cooperating in period t was about 55 percentage points higher for previous cooperators than for previous non-cooperators, which shows the considerably high persistence in cooperation activities from period to period.

In addition, although the probability of permanence in the same state decreases as the period of observation extends, the last transition matrices ( $\mathrm{t}-3$ and $\mathrm{t}$ ) still show a high level of persistence in the decisions to engage in cooperation in innovation: almost $57 \%$ of cooperators and $73 \%$ of non-cooperators remain in their initial state after six to eight years, with very similar figures for the balanced panel.

[Insert Table 3 around here]

In any case, the probability of persisting in cooperation agreements in innovation in the case of Spanish firms seems not to be as high as is observed in R\&D activities that have been reported in previous studies, nor are transitions as infrequent (see, for instance, ArquéCastells, 2013). ${ }^{6}$ This can be related to the fact that a firm may decide to carry cooperation

\footnotetext{
${ }^{6}$ Also for a panel of Spanish manufacturing firms, Arqué-Castells (2013) report that during the period 1998$2009,89 \%$ of $R \& D$ performers in one year persisted in $R \& D$ the subsequent year, while $11 \%$ ceased their $R \& D$
} 
activities as a strategy to innovate; however, this is not the only way to develop innovation, so that according to different objectives, it may not always be necessary to follow cooperative agreements. In addition, the continuity of a cooperation agreement depends not only on the firm itself, but also on the decision by the counterparty as to whether to continue with the alliance, which can thereby make this category of activities less continuous.

Table 4 shows the transition probabilities of cooperation agreements for the three types of partners: First, there are hardly any differences between the unbalanced panel and the smaller balanced panel. We also observe that persistence in cooperation at the firm level is larger with respect to research institutions and universities, with more than $68 \%$ of firms that cooperated in one period persisted in the subsequent period, followed by cooperators with clients or suppliers, with a persistence rate of $63 \%$.

In the case of cooperation with competitors, about $52 \%$ of cooperation agreements persisted in $\mathrm{t}+1$, which was 16 percentage points lower than was true for cooperation with institutions. Among other reasons, one could point to the fact that cooperating with competitors may follow strategic reasons that can vary substantially over time depending on market conditions, the economic cycle, and the situation of the two firms. By contrast, cooperation agreements with institutions may follow the structural objectives of the cooperating firm, which tend to be of a long-term nature.

In any case, transitions are relatively frequent in all of the cases. For instance, nearly $32 \%$ of cooperators with institutions in one wave ceased such alliances in the following wave, which

activities. Similarly, $95 \%$ of non R\&D performers maintained their status the next period while only $5 \%$ entered into R\&D. 
is the lowest share (this probability increases in the case of vertical cooperation to $37 \%$, and sums up to nearly $48 \%$ in horizontal cooperation). This higher stability for the case of technological cooperation with research institutions and universities can be related to the fact that firms that engage in such alliances do not look for merely short-term alliances but more for a way to carry out a long-term innovation strategy. Indeed, institutional cooperation allows low-risk access to specialist knowledge that is generally focused on basic R\&D, so that it is sensible to find longer-term strategic alliances (Arranz and Arroyabe, 2008; Woerter, 2012).

[Insert Table 4 around here]

\section{Empirical model}

Our empirical approach follows the definition of cooperation persistence as state dependence: Cooperation in innovation activities in the past increases the probability of engaging in such arrangements currently. Consequently, the study considers a dynamic random effects probit model that allows for state dependence and unobserved individual heterogeneity to analyse the discussed causal relationship.

The latent variable model is specified as follows:

$$
\begin{aligned}
& y_{i t}^{*}=\gamma y_{i t-1}+x_{i t}^{\prime} \beta+\alpha_{i}+\varepsilon_{i t}, \quad y_{i t}=1\left[y_{i t}^{*}>0\right] \\
& i=1, \ldots, N ; t=2, \ldots, T
\end{aligned}
$$

where $y_{i t}^{*}$ is the latent dependent variable that measures the difference between benefits and costs that firm $i$ obtains during the current period $t$ by cooperating in innovation with other 
firms or institutions. Instead of observing $y_{i t}^{*}$ we observe only a binary variable $y_{i t}$ that indicates the sign of $y_{i t}^{*}$. Thus, 1[.] is an indicator function that takes on the value 1 whenever the statement in brackets is true, and zero otherwise.

$y_{i t-1}$ is an indicator for cooperation during the period $\mathrm{t}-1$ and captures the previous cooperation experience; and $\gamma$ is the parameter of interest that indicates the level of persistence in the dependent variable. A positive and statistically significant estimate of $\gamma$ identifies the presence of persistence in the decision to engage in cooperation agreements for innovation. The higher is the value of $\gamma$, the higher is the level of persistence in cooperation. $x_{i t}$ is a vector of observable characteristics of the firm that may be associated with cooperation in innovation, and $\beta$ the corresponding vector of parameters; $\alpha_{i}$ are unobserved individual-specific random effects that are assumed to be uncorrelated with the independent variables; ${ }^{7}$ and $\varepsilon_{i t}$ is a time- and individual-specific error term that is assumed to be distributed as $N(0,1)$.

\footnotetext{
${ }^{7}$ A fixed effects model, in which the individual specific effect is correlated with the independent variables, suffers from the so-called "incidental parameter problem", which makes it unfeasible to estimate. For this reason, the literature generally assumes a random effects specification in this kind of analysis (Hsiao, 2003; Wooldridge, 2010). In addition, since we are considering a sample of the whole population of Spanish firms -i.e., a random sample from a large population -- the random effects model would be more appropriate than the fixed effects model based on theoretical grounds (Baltagi, 2005). Also, following Mundlak (1978) and Hsiao (2003), we prefer the random effects model because it allows for the treatment of omitted factors that affect the dependent variable as random errors instead of as constants.
} 
The correlation between the compound error term in equation (1) in any two periods is $\rho=\sigma_{\alpha}^{2} /\left(\sigma_{\alpha}^{2}+1\right)$. In this context, $\rho$ represents the percentage of the variance of the compound error term $\left(\alpha_{i}+\varepsilon_{i t}\right)$ that is explained by unobserved heterogeneity. Testing the statistical significance of this parameter leads to an easy test for the presence of unobserved effects: the relevance of the random effects estimator over the pooled estimator.

To estimate our parameter of interest $(\gamma)$ consistently, it is necessary to account for both unobserved heterogeneity and the initial conditions (Heckman, 1981a, b; Wooldridge, 2005). We account for both of them using the Wooldridge (2005) approach. Specifically, it assumes that the unobserved individual heterogeneity depends on the initial conditions $\left(y_{i 0}\right)$ and the time-varying exogenous variables, namely:

$$
\alpha_{i}=\delta_{0}+\delta_{1} y_{i 0}+\delta_{2} \bar{x}_{i}+u_{i}
$$

where $\bar{x}_{i}$ represents the means of time-variant exogenous variables; $u_{i}$ is assumed to be distributed $N\left(0, \sigma_{u}^{2}\right)$ and independently of the explanatory variables, the initial conditions $\left(y_{i 0}\right)$, and the idiosyncratic error term $\left(\varepsilon_{i t}\right) .{ }^{8}$ Substituting equation (2) into equation (1) gives:

$$
y_{i t}^{*}=\gamma y_{i t-1}+x_{i t}^{\prime} \beta+\delta_{0}+\delta_{1} y_{i 0}+\delta_{2} \bar{x}_{i}+u_{i}+\varepsilon_{i t}
$$

\footnotetext{
${ }^{8}$ Since the regressors exhibit too little time variation (within variation) and given the high correlation between the variables and their within means (see Table 2 and Table A2 in the Appendix), we are not able to identify $\delta_{2}$; hence, we followed the strategy that was adopted by Raymond et al. (2010) and assume that the unobserved individual effects are correlated only with the initial values of $y_{i t}$. As a consequence, the results on the effects of the explanatory variables should be interpreted with caution.
} 
In this case, the relative importance of the unobserved effect is measured as $\rho=\sigma_{u}^{2} /\left(\sigma_{u}^{2}+1\right)$.

We may wonder whether the state dependence that is measured by the parameter $\gamma$ is genuine and specific of cooperative agreements in innovation and not just caused by persistence in $R \& D$. That is, we need to be sure that we are not omitting the effect of carrying out previous $\mathrm{R} \& \mathrm{D}$ activities and picking it up as persistence in cooperation in innovation. In order to disentangle cooperation persistence from $R \& D$ persistence, we consider another specification that includes the lagged cooperation dummy variable and a lagged R\&D dummy variable (with the corresponding initial conditions). ${ }^{9}$ The $R \& D$ dummy variable picks up whether or not the firm engaged in internal and/or external R\&D activities.

This way, if the coefficient that accompanies $R \& D$ in the previous period is significantly different from zero, we could say that prior investment in R\&D influences current cooperation in innovation activities. Therefore, if after accounting for this impact of previous $R \& D$, the parameter on cooperation keeps being significant, we could conclude that the result for cooperation persistence is maintained on top of the persistence that is found for R\&D. In such a case, the state dependence found would be genuine and specific of cooperation alliances and not just caused by prior R\&D activities.

\section{Results}

\subsection{Persistence in collaborative behaviour. Is this persistence genuine?}

\footnotetext{
${ }^{9}$ We thank an anonymous referee for pointing this out.
} 
The results for the main regression estimations are given in Table 5. As is shown, the statistical significance of the panel-level variance component over the total variance $(\rho)$ indicates that the random effects estimator is preferred over the pooled probit estimator. In the first column we report the marginal effects from the estimation of the dynamic random effects probit model taking into account the unobserved individual heterogeneity and assuming that the initial conditions are exogenous. The average marginal effect of the lagged dependent variable is 0.47 , positive, and highly significant. This result indicates that firms are persistent in carrying out cooperation activities as a strategy to undertake their innovation activities.

[Insert Table 5 around here]

However, since the persistence of engaging in cooperation in innovation may be spurious when the individual effects and the initial conditions are not addressed, these results can be contrasted with the estimates that are obtained under the assumption that the initial conditions are correlated with the individual effects, as presented in the second column. These Wooldridge estimates yield an average marginal effect of 0.34: Firms that participated in cooperation agreements at $\mathrm{t}-1$ have a probability of cooperating at $\mathrm{t}$ that is around 34 percentage points higher than firms that did not cooperate at $\mathrm{t}-1$.

Two main conclusions follow: First, there is evidence of the existence of a behavioural effect in the sense that the decision to cooperate in a period enhances the probability of being a cooperator in subsequent periods, as is expected from our first hypothesis. That is, our results suggest a significant state dependence effect for cooperation in innovation activities. Second, 
in line with previous findings in the literature, the hypothesis of exogenous initial conditions leads to overestimation of the degree of persistence. ${ }^{10}$

While taking into account the dynamic behaviour of cooperation, we also observe that the importance that is attributed to sources of information that is publicly accessible, the use of protection methods, $\mathrm{R} \& \mathrm{D}$ intensity, firm size, and the fact of belonging to a group of enterprises affect positively and significantly the probability to cooperate. Furthermore, it is worth noting that the firm's decision to cooperate in innovative activities depends significantly on public funding (local, national and European).

This result is in accordance with many studies that analyse the relationship between cooperation in innovation and subsidies (Busom and Fernández-Ribas, 2008; Arranz and Arroyabe, 2008; Abramovsky et al., 2009) and with evidence that subsidies that are designed to encourage innovation activities could alleviate barriers to cooperation. Of course this dependence of cooperation on public funding can be a problem for the long-term innovation strategy of the firm, since not receiving public funds because of government budget cuts could force the firm to withdraw from its cooperation agreements.

\footnotetext{
${ }^{10}$ Because in the PITEC surveys the cooperation variable is related to a 3-year period, part of this persistence may be due to a one-year overlap. However, we carried out the same analysis with the use of a sample without any overlap in the measurement period (i.e., considering three waves: 2004 (2002-2004), 2007 (2005-2007), and 2010 (2008-2010)), and the resulting conclusions were virtually unchanged. The results can be provided by the authors upon request. The reason why we did not opt for this last sample was that this would imply losing observations. For the case of innovation persistence, Raymond et al. (2010) found that the effect of the overlapping year is not important. We thank an anonymous referee for raising this point.
} 
We turn now to find evidence on the extent to which the cooperation persistence that is found in our previous estimation is just related to $R \& D$ persistence or is found on top of it. In the third column of Table 5 we consider a specification that includes the lagged cooperation dummy variable and a lagged R\&D dummy variable (with the corresponding initial conditions). We observe that the parameters on cooperation and $\mathrm{R} \& \mathrm{D}$ in $\mathrm{t}-1$ are both significant; consequently, after accounting for the impact of prior R\&D activities, the results on cooperation persistence are maintained.

This points to the fact that the true state dependence that is found here is specific to cooperative agreements and not just caused by previous R\&D investments. Note that we also included an interaction term between both variables, in order to show how persistence in cooperation and in $\mathrm{R} \& \mathrm{D}$ are related. With respect to this interaction term, the results do not show any substantial cross effect. It seems therefore that there is not any additional impact when a firm follows both the strategy of cooperating and investing in $R \& D$ in a previous period, on the probability of cooperating in t. In all, our results allow us to conclude that firms cooperate persistently on top of the impact of previous R\&D investments.

\subsection{Robustness check on the general pattern of persistence in cooperation}

In order to explore the robustness of the results encountered so far, in this section we perform some additional analyses. Initially, we compare the results of the estimations for the unbalanced panel with those of the balanced one (Columns 4 to 6 of Table 5). By and large, the results for the two datasets are very similar, which confirms the evidence in favour of persistence in cooperation in innovation activities. From this point forward, all the regressions that are described will be only for the unbalanced panel, since it allows us to obtain more 
precise estimates as it considers a larger number of observations and for a greater variety of firms. Additionally, it allows controlling partly for survival biases as firms are allowed to enter and exit the sample at any period.

With the aim of analysing the strength of the persistence found in cooperation activities, the first two columns in Table 6 refer to the same estimations as those given in Table 5, but now including an additional variable that takes the value 1 if the firm decided to cooperate two periods before (t-2), irrespectively of what was done in period t-1. As is observed, state dependence is also observed in the case of a longer time span, which in our case corresponds to four to six years, although with a much lower intensity. ${ }^{11}$

[Insert Table 6 around here]

However, what happens when a firm that has been cooperating in innovation activities stops doing it? Is this firm more able to re-start cooperating than can those that did not cooperate before? Columns (3) and (4) in Table 6 include an explanatory variable Coop $_{\mathrm{t}-2 / \mathrm{t}-1=0}$, that takes the value 1 if the firm cooperated in $\mathrm{t}-2$, restricted to the fact of not having carried out cooperation activities in $\mathrm{t}-1$. Under the same scenario of non-cooperation in $\mathrm{t}-1$, the value of

\footnotetext{
${ }^{11}$ The $\mathrm{t}-2$ lagged cooperation dummy variable is probably the initial condition for firms that are in the sample for just two periods. However, when we repeated the same regressions with the balanced panel, where all firms remain through all of the waves in the survey, the initial conditions are still insignificant. The results can be provided upon request. This implies that there is not significant correlation between the firm's initial innovation status and the unobserved heterogeneity, which could be due to the shortness of the panel. We thank a referee for raising this point.
} 
this variable is 0 if the firm also did not cooperate either in $\mathrm{t}-2$. These new estimations can be understood as a robustness check.

Recall that our dataset prevents us from observing individual collaborative agreements between firms, so that persistence is understood as continuously collaborating, irrespective of whether it is with the same firm or different firms in each period. As a consequence of this characteristic of the dataset, we are assuming that a firm that collaborates with different firms in each period generates the same observed pattern as a firm that cooperated with the same single firm over the whole period.

The consideration of this new variable $\operatorname{Coop}_{\mathrm{t}-2 / \mathrm{t}-1=0}$ would allow us to analyse specifically whether a firm that has cooperated in the past and has stopped doing it, still has a higher probability of engaging in new alliances, as compared to non-cooperators (at least noncooperators in two continuous waves, that is, firms without cooperation activities in at least six years). This new cooperation agreement can be with a different firm/institution or with the same one as in the past but, in any case, under a new agreement or cooperation project.

According to our estimates, firms that were not engaged in cooperation activities in $\mathrm{t}-1$ but with previous experience in $\mathrm{t}-2$ have a significantly higher probability of engaging in cooperation agreements in $\mathrm{t}$, as compared with those that did not carry out cooperation activities in the past (at least for the time periods that fall under control in our sample). This past dependence is much lower than in the case of cooperating continuously, but still points to the fact that once a firm begins to collaborate, it will gain experience and develop a reputation as a partner, which persists over time and allows starting new cooperation agreements more easily. 
This result complements the idea given in our first hypothesis that prior collaborative experience in innovation activities influence the likelihood of persisting in innovation alliances. Now we can affirm that it also seems to ease the formation of new alliances.

As a final exercise, we estimated separate regressions for the manufacturing and service sectors to see to what extent the phenomenon of persistence found above may be different between the two sectors. A likelihood ratio test (LR) that compares the coefficients that were obtained for the full sample of firms with the ones that are obtained in the two separate subsamples (LR chi2(30)=29.11, p-value: 0.015) points to the existence of significant differences between manufacturing and service firms in the set of factors that drive the decision to cooperate. ${ }^{12}$

According to our results for the separate samples (columns 5 and 6 in Table 6), we do not observe remarkable changes for most of the coefficients -- neither in sign or significance. The most striking difference between sectors is found with respect to firm size. While in the manufacturing sector small-medium and large firms have a significant and positive higher effect on the decision to cooperate than do the smallest firms (the reference category), in the services sector only firms with more than 500 employees are more likely to cooperate in innovation activities than the smallest ones. This result is in line with the one obtained in Abramovsky et al. (2009) that studied the determinants of cooperative innovation in a set of

\footnotetext{
${ }^{12}$ In the same spirit, we also run separate regressions for the four size classes of the firms that we use in this paper. A likelihood ratio test does not reject the null of equality of parameters (LR chi2(122)=141.30, p-value: $0.0895)$.
} 
four European countries, in which firm size was only statistically significant for the manufacturing sector in Spain.

In addition, it seems that a greater use of protection methods has a lower impact on cooperation in the manufacturing sector than in services. The impact of internal $\mathrm{R} \& \mathrm{D}$ intensity on cooperation appears to be clearer in the manufacturing sector, implying that the firm's decision to cooperate in innovation activities depends significantly on internal $R \& D$ expenditures in this sector to a greater extent than is true in services. The same happens with the variable that proxies for the fact of belonging to a group, since being a member of an enterprise group has a greater influence on cooperation in the manufacturing sector than in services. Such differences that are detected between the manufacturing and the service sectors are presumably due to sectoral differences in the nature of innovations (see Arvanitis and Bolli, 2013). With respect to the time dummy variables, we detect significant temporal effects that influence the probability of cooperation in the manufacturing sector but not in services.

The results also showed that the differences with respect to the level of persistence are minimal between the two sectors. Since our key variable is lagged cooperation, in order to test if there are sectoral differences only with respect to this variable, we re-ran our main regression and introduced an interaction term between the lagged cooperation variable and a sectoral dummy variable. The results obtained showed that this interaction term is not 
significantly different from zero, which leads us to conclude that persistence in cooperation activities does not differ significantly across these two sectors. ${ }^{13}$

\subsection{Persistence pattern of collaboration for different types of partners}

We turn now to analyse whether there are different persistence patterns according to the type and the diversity of partners as stated in the third hypothesis of this paper. Initially, we explore the degree of persistence in cooperation when considering three types of partners separately: customers and/or suppliers; competitors; and research institutions. To allow for likely interdependencies between firms' decisions to engage in cooperation with different types of partners at the same time and avoid the possible bias resulting from modelling the decisions separately, we estimate a multivariate dynamic random effects probit model. We follow the empirical strategy that was adopted by Devicienti and Poggi (2011), who also assume the Wooldridge initial conditions approach.

Columns (1) to (3) in Table 7 show the estimates of our specification for the three types of partners separately. Again, after taking into account the assumption of the initial conditions correlated with the unobserved individual effects, we obtain lower parameters for persistence than with the hypothesis of exogenous initial conditions. ${ }^{14}$ The Wooldridge estimates yield a marginal effect of 0.26 for vertical cooperation: Firms that performed cooperation agreements

\footnotetext{
13 Therefore, it seems that the differences raised by the LR test are due to some of the determinants of cooperation that we have considered as control variables but not the persistence in cooperation, which is the main topic in this paper.
}

\footnotetext{
${ }^{14}$ We do not offer the results without the Wooldridge correction to save space. They can be provided by the authors upon request.
} 
with clients or suppliers at $\mathrm{t}-1$ have a probability of cooperating at $\mathrm{t}$ around 26 percentage points higher than do firms that did not cooperate at t-1 with this type of partner.

The same applies for the case of cooperation with universities or research institutions, although with a slightly lower probability ( 23 percentage points). In the case of cooperating with competitors, this probability is 12 percentage points, much lower but still significant.

[Insert Table 7 around here]

Several conclusions are worth pointing out. First, irrespective of the type of partner, there exists a behavioural effect in the sense that the decision to cooperate with one type of partner in one period enhances the probability of being the same kind of cooperator in subsequent periods. These results suggest a significant state dependence effect for cooperation activities even once we consider separately the different types of alliances.

Second, among the reasons behind the highest persistence in the case of collaboration with customers, clients, and research institutions one may think of the relatively limited risk of information' spilling over, as compared to the risk in agreements with competitors. In the case of collaboration with competitors, due to the similar knowledge both firms share, the capacity for the absorption of knowledge spillovers and as a consequence of creating free-ridership is particularly important (Nooteboom, 2004). As a consequence, agreements of cooperation with competitors are not only scarcer but also less permanent.

Overall, alliances with customers may present the highest degree of persistence due to the strategic importance of clients as collaboration partners through the whole innovation process, 
from early phases to access novel ideas to later stages enhancing its wider diffusion, which would lead to more durable innovation alliances.

Following the arguments that underlie hypothesis 4, cooperation with one type of partner may be affected by the experience in cooperation with partners of a different nature. In order to account for this possible crossed-persistence, we augment our model by incorporating not only the past alliance engagement in the same type of partnership but also variables that consider if the firm was previously engaged in an alliance with each of the other two types of partners. This specification allows us to analyse whether firms with experience in technological cooperation agreements of one type are likely to form alliances with a different partnership class. The results are provided in Columns 4 to 6 in Table 7.

Once again the magnitude of persistence in cooperation is significantly positive and of a similar magnitude to the coefficients that are obtained without including the specific interrelations across types of partners. That is, persistence in the case of institutional as well as vertical cooperation is higher than is true of collaboration agreements with competitors. However, only cooperation agreements with institutional partners significantly influence the likelihood of cooperating in the future with a different partnership class, and with a much lower intensity than is the case for the same partnership group.

For instance, we find that firms that performed cooperation agreements with research institutions at $\mathrm{t}-1$ have a probability of cooperating with clients or suppliers at $\mathrm{t}$ around 3 percentage points higher than do firms that did not cooperate at $\mathrm{t}-1$ with such institutions. Among the reasons that underlie such influence of past alliances with institutions, we may think on the idea that relations with research centres or universities may allow the firm to 
obtain higher insights on future opportunities for innovation and the creation of a nextgeneration technology. Subsequent to this, the firm may need to start technological collaboration agreements with clients or suppliers so that they adapt their processes to this new technology.

In any case, as evidenced by the low value of the coefficient of this cross-effect, we can conclude that the influence of prior cooperation with research institutions on the probability of cooperating with clients or suppliers, although significant, is of limited importance.

\section{Conclusions}

Our study is an attempt to analyse persistence in cooperation in innovation activities and, as a consequence, understand innovation in a globalised environment. Initially, persistence in cooperation agreements is appealing, as it provides firms with a stream of information that becomes available thanks to being embedded in a network. The results show that there is a substantial persistence in cooperation in innovation in the case of Spanish firms. After correcting for the impact of observed and unobserved firm characteristics, a firm that cooperates in $\mathrm{t}-1$ has a probability of cooperating in that is around 33 percentage points higher than that of a firm that did not cooperate in the previous period.

It has been shown that such persistence is genuine in the sense that it is beyond the persistence that is observed in $\mathrm{R} \& \mathrm{D}$. This could be explained by the accumulation of knowledge and capabilities that may be gained from past experiences in cooperation projects, the barriers to entry and exit that can arise due to sunk costs, and the success and reliability in past cooperation agreements. In addition, we observe that firms with higher incoming 
spillovers, higher R\&D intensity, large firms, and firms that belong to a group of enterprises as well as firms that use IP protection methods (such as patenting or registering an industrial design, trademark, or copyright) are more persistent in their technological collaborative agreements.

When taking into account the different types of partnership, we conclude that the highest persistence is found in the case of vertical collaboration and cooperation with institutions. One potential explanation may be related to the relatively limited risk of spillovers in those types of alliances as compared to the risks in agreements with competitors. Finally, cooperation agreements with universities and research institutes increase, although very slightly, the likelihood of cooperating in the future with a different type of partner, while vertical and horizontal collaboration in the past does not appear to influence cooperation with other types of partners.

From a policy perspective, the fact that cooperation in innovation is state dependent implies that collaboration-stimulating policy measures, such as government support programmes, should have a deeper effect because they not only affect current collaboration agreements but also are likely to induce a permanent change in favour of cooperation. In addition, since persistence is also driven by certain individual characteristics of the firms, they could be taken into account when designing policies to stimulate cooperation in a persistent way. For instance, policy makers could also encourage the absorptive capacity of firms, which would improve their ability to form long-term alliances. 
Acknowledgements: Erika Badillo wishes to acknowledge the financial support from the AGAUR (Generalitat de Catalunya) through "the grant for universities and research centres for the recruitment of new research personnel (FI-DGR 2011)”. Rosina Moreno acknowledges financial support provided by the Ministerio de Economía y Competitividad for the project entitled "Innovation and territory. Technological collaboration, international competitiveness and location factors", ECO2014-59493-R, as well as for the project "Redes de colaboración tecnológica e innovación. Determinantes y efectos sobre la competitividad de las empresas españolas” funded by the Fundación BBVA Ayudas a Proyectos de Investigación 2014. 


\section{References}

Abramovsky, L., Kremp, E., López, A., Schmidt, T., \& Simpson, H. (2009). Understanding co-operative innovative activity: Evidence from four European countries. Economics of Innovation and New Technology, 18(3), 243-265.

Archibugi, D., \& Coco, A. (2004). International partnerships for knowledge in business academia: A comparison between Europe and USA. Technovation, 24(7), 517-528.

Arqué-Castells, P. (2013). Persistence in R\&D performance and its implications for the granting of subsidies. Review of Industrial Organization, 43, 193-220.

Arranz, N., \& Arroyabe, J.C.F. (2008). The choice of partners in R\&D cooperation: An empirical analysis of Spanish firms. Technovation, 28, 88-100.

Arvanitis, S., \& Bolli, T. (2013). A comparison of national and international innovation cooperation in five European countries. Review of Industrial Organization, 43, 163-191.

Ahuja, G. (2000). Collaboration networks, structural holes, and innovation: A longitudinal study. Administrative Science Quarterly, 45, 425-455.

Baltagi, B.H. (2005). Econometric Analysis of Panel Data. Wiley and Sons, Chichester.

Bayona, C., Gracia-Marco, T., \& Huerta, E. (2001). Firms' motivation for cooperative R\&D: An empirical analysis of Spanish firms. Research Policy, 30(8), 1289-307.

Belderbos, R., Carree, M.A., Diederen, B., Lokshin, B., \& Veugelers, R. (2004). Heterogeneity in $R \& D$ co-operation strategies. International Journal of Industrial Organization, 22(8-9), 1237-63.

Belderbos, R., Gilsing, V., \& Lokshin, B. (2012). Persistence of, and Interrelation Between, Horizontal and Vertical Technology Alliances. Journal of Management, 38(6), 18121834. 
Busom, I., \& Fernández-Ribas, A. (2008). The impact of firm participation in R\&D programmes on R\&D partnerships. Research Policy, 37(2), 240-257.

Cassiman, B., \& Veugelers, R. (2002). R\&D cooperation and spillovers: Some empirical evidence from Belgium. The American Economic Review, 92(4), 1169-1184.

Clausen, T., Pohjola, M., Sapprasert, K., \& Verspagen, B. (2012). Innovation strategies as a source of persistent innovation. Industrial and Corporate Change, 21(3), 553-585.

Cohen, W.M., \& Klepper, S. (1996). A reprise of size and R\&D. Economic Journal, 106, 925951.

Cohen, W.M., \& Levinthal, D.A. (1989). Innovation and learning: The two faces of R\&D. Economic Journal, 99, 569-596.

Cohen, W.M., \& Levinthal, D.A. (1990). Absorptive capacity: A new perspective of learning and innovation. Administrative Science Quarterly, 35(1), 128-152.

Devicienti, F., \& Poggi, A (2011). Poverty and social exclusion: Two sides of the same coin or dynamically interrelated processes? Applied Economics, 43, 3549-71.

Dyer, J. H., \& Singh, H. (1998). The relational view: Cooperative strategy and sources of inter-organizational competitive advantage. Academy of Management Review, 23, 660679.

Eisenhardt, K. M., \& Martin, J. A. (2000). Dynamic capabilities: What are they? Strategic Management Journal, 21, 1105-21.

Fritsch, M., \& Lukas, R. (2001). Who cooperates on R\&D? Research Policy, 30(2), 297-312.

Granovetter, M. (1985). Economic action and social structure: The problem of embeddedness. American Journal of Sociology, 91, 481-510. 
Gulati, R. (1995). Social structure and alliance formation patterns: A longitudinal analysis. Administrative Science Quarterly, 40, 619-652.

Gulati, R. (1999). Network location and learning: The influence of network resources and firm capabilities on alliance formation. Strategic Management Journal, 20, 97-420.

Heckman, J.J. (1981a). Heterogeneity and state dependence. In S. Rosen (Ed.), Studies in labor markets, 91-140. Chicago: Chicago University Press.

Heckman, J.J. (1981b). The incidental parameters problem and the problem of initial conditions in estimating a discrete time-discrete data stochastic process. In C.F. Manski and D. McFadden (Eds.), Structural Analysis of Discrete Data with Econometric Applications, MIT Press, Cambridge, MA, 114-178.

Hernán, R., Marin, P., \& Siotis, G. (2003). An empirical analysis of the determinants of Research Joint Venture Formation. Journal of Industrial Economics, 51, 75-89.

Hoang, H., \& Rothaermel, F. (2005). The effect of general and partner specific alliance experience on joint R\&D project performance. Academy of Management Journal, 48(2), $332-345$.

Hsiao, C. (2003). Analysis of Panel Data. Cambridge University Press.

Jacob, J., Belderbos, R., \& Gilsing, V. (2013). Technology alliances in emerging economies: Persistence and interrelation in European firms' alliance formation. R\&D Management, 43(5), 447-460.

Jensen, M., Johnson, B., Lorenz, E., \& Lundvall, B.-Å. (2007). Forms of knowledge and modes of innovation. Research Policy, 36(5), 680-693. 
Le Bas, C., Mothe, C., \& Nguyen-Thi, T.U. (2011). Technological innovation persistence: Literature survey and exploration of the role of organizational innovation, CEPS Instead, Working Paper 2011-54.

Levitt, B., \& March, J.G. (1988). Organizational learning. Annual Review of Sociology, 14, 314-340.

López, A. (2008). Determinants of R\&D cooperation: Evidence from Spanish manufacturing firms. International Journal of Industrial Organization, 26, 113-136.

Lundvall, B.-Å. (1988). Innovation as an interactive process: From user-producer interaction to the national system of innovation. In: Dosi, G. Freeman, C., Nelson, R., Silverberg, G., Soete, L. (Eds.), Technical Change and Economic Theory. Pinter, London, 349-369.

Lundvall, B.- $\AA$. (2004). The economics of knowledge and learning. In J.L. Christensen and B.-Å. Lundvall (Eds.), Product Innovation, Interactive Learning and Economic Performance (Research on Technological Innovation and Management Policy, vol 8). Emerald Group Publishing Ltd., 21-42.

Miotti, L., \& Sachwald, F. (2003). Cooperative R\&D: Why and with whom? An integrated framework of analysis. Research Policy, 32(8), 1481-1499.

Mundlak, Y. (1978). On the pooling of time series and cross section data. Econometrica, 46, $69-85$.

Nieto, M.J., \& Santamaría, L. (2007). The importance of diverse collaborative networks for the novelty of product innovation. Technovation, 27, 367-377.

Nooteboom, B. (2004). Inter-firm collaboration, learning and networks: An integrated approach. London: Routledge. 
Peters, B. (2009). Persistence of innovation: Stylised facts and panel data evidence. The Journal of Technology Transfer, 34, 226-243.

Powell, W., Koput, K., \& Smith-Doerr, L. (1996). Interorganizational collaboration and the locus of innovation: Networks of learning in biotechnology. Administrative Science Quarterly, 41(1), 116-146.

Raymond, W., Mohnen, P.A., Palm, F., \& Van der Loeff, S.S. (2010). Persistence of innovation in Dutch manufacturing: Is it spurious? The Review of Economics and Statistics, 92, 495-504.

Röller, L., Siebert, R., \& Tombak, M. (2007). Why firms form (or do not form) RJVS. The Economic Journal, 117(522), 1122-1144.

Sutton, J. (1991). Sunk costs and market structure (MIT Press, London).

Tether, B.S. (2002). Who co-operates for innovation, and why: An empirical analysis. Research Policy, 31(6), 947-967.

Triguero, Á., \& Córcoles, D. (2013). Understanding innovation: An analysis of persistence for Spanish manufacturing firms. Research Policy, 42(2), 340-352.

Veugelers, R., \& Cassiman, B. (1999). Make and buy in innovation strategies: Evidence from Belgian manufacturing firms. Research Policy, 28, 63-80.

Veugelers, R., \& Cassiman, B. (2005). R\&D cooperation between firms and universities. Some empirical evidence from Belgian manufacturing. International Journal of Industrial Organization, 23(5-6), 355-379.

Woerter, M. (2012). Technological proximity between firms and universities and technology transfer. Journal of Technology Transfer, 37, 828-866. 
Wooldridge, J.M. (2005). Simple Solutions to the Initial Conditions Problem in Dynamic Nonlinear Panel Data Models with Unobserved Heterogeneity. Journal of Applied Econometrics, 20, 39-54.

Wooldridge, J.M. (2010). Econometric analysis of cross section and panel data. Third Edition. Cambridge, MA: MIT Press. 


\section{Tables}

Table 1. Characteristics of the panel datasets

\begin{tabular}{lcc}
\hline & Unbalanced panel & Balanced panel \\
\hline Number of observations & 25,364 & 16,016 \\
Number of firms & 7,566 & 4,004 \\
Number of consecutive obs. per firm & $>=2$ & 4 \\
Average number of consecutive obs. & 3.4 & 4 \\
\hline
\end{tabular}

Table 2. Descriptive statistics of variables in the empirical analysis

\begin{tabular}{|c|c|c|c|c|c|c|c|c|c|c|c|c|}
\hline \multirow[b]{4}{*}{ Cooperation t-1 } & \multicolumn{6}{|c|}{ Unbalanced } & \multicolumn{6}{|c|}{ Balanced } \\
\hline & \multirow{2}{*}{ mean } & \multicolumn{3}{|c|}{ std. dev. } & \multirow{2}{*}{$\min$} & \multirow{2}{*}{$\max$} & \multirow{2}{*}{ mean } & \multicolumn{3}{|c|}{ std. dev. } & \multirow{2}{*}{$\min$} & \multirow{2}{*}{$\max$} \\
\hline & & overall & between & within & & & & overall & between & within & & \\
\hline & 0.382 & 0.486 & 0.414 & 0.268 & 0 & 1 & 0.409 & 0.492 & 0.395 & 0.293 & 0 & 1 \\
\hline Incoming spillovers & 0.363 & 0.277 & 0.240 & 0.151 & 0 & 1 & 0.380 & 0.275 & 0.223 & 0.161 & 0 & 1 \\
\hline Legal (IP) protection & 0.357 & 0.479 & 0.408 & 0.266 & 0 & 1 & 0.377 & 0.485 & 0.387 & 0.291 & 0 & 1 \\
\hline R\&D intensity & 0.075 & 0.245 & 0.240 & 0.083 & 0 & 2 & 0.071 & 0.233 & 0.216 & 0.086 & 0 & 2 \\
\hline Firm size & 314.244 & 1430.165 & 1440.760 & 280.152 & 10 & 41168 & 334.356 & 1305.782 & 1277.710 & 269.809 & 10 & 37274 \\
\hline Local funding & 0.300 & 0.458 & 0.390 & 0.252 & 0 & 1 & 0.321 & 0.467 & 0.379 & 0.273 & 0 & 1 \\
\hline National funding & 0.269 & 0.444 & 0.370 & 0.250 & 0 & 1 & 0.296 & 0.456 & 0.366 & 0.273 & 0 & 1 \\
\hline European funding & 0.074 & 0.261 & 0.220 & 0.139 & 0 & 1 & 0.083 & 0.276 & 0.228 & 0.155 & 0 & 1 \\
\hline Belongs to a group & 0.416 & 0.493 & 0.472 & 0.147 & 0 & 1 & 0.442 & 0.497 & 0.470 & 0.160 & 0 & 1 \\
\hline
\end{tabular}

Table 3. Transition probabilities matrix

\begin{tabular}{|c|c|c|c|c|c|}
\hline \multirow[b]{3}{*}{$\begin{array}{l}\text { Cooperation } \\
\text { in }\end{array}$} & & \multicolumn{4}{|c|}{ Cooperation in $\mathrm{t}$} \\
\hline & & \multicolumn{2}{|c|}{ Unbalanced panel } & \multicolumn{2}{|c|}{ Balanced panel } \\
\hline & & $\begin{array}{c}\text { Non- } \\
\text { cooperation }\end{array}$ & Cooperation & $\begin{array}{c}\text { Non- } \\
\text { cooperation }\end{array}$ & Cooperation \\
\hline \multirow{2}{*}{$\mathrm{t}-1$} & Non-cooperation & 83.70 & 16.30 & 82.50 & 17.50 \\
\hline & Cooperation & 29.24 & 70.76 & 27.39 & 72.61 \\
\hline \multirow{2}{*}{$\mathrm{t}-2$} & Non-cooperation & 78.22 & 21.78 & 77.63 & 22.37 \\
\hline & Cooperation & 39.01 & 60.99 & 36.99 & 63.01 \\
\hline \multirow{2}{*}{$\mathrm{t}-3$} & Non-cooperation & 73.35 & 26.65 & 73.35 & 26.65 \\
\hline & Cooperation & 43.43 & 56.57 & 42.89 & 57.11 \\
\hline
\end{tabular}

Table 4. Transition probabilities matrix - Type of cooperation

\begin{tabular}{|c|c|c|c|c|c|}
\hline \multirow{5}{*}{$\begin{array}{c}\text { Vertical } \\
\text { cooperation } \\
\text { in } \mathbf{t}-1 \\
\end{array}$} & \multirow{5}{*}{$\begin{array}{c}\text { Non-cooperation } \\
\text { Cooperation }\end{array}$} & \multicolumn{2}{|c|}{ Unbalanced panel } & \multicolumn{2}{|c|}{ Balanced panel } \\
\hline & & $\begin{array}{c}\text { Non- } \\
\text { cooperation }\end{array}$ & Cooperation & $\begin{array}{c}\text { Non- } \\
\text { cooperation }\end{array}$ & Cooperation \\
\hline & & \multicolumn{4}{|c|}{ Vertical cooperation in $\mathbf{t}$} \\
\hline & & 89.10 & 10.90 & 88.19 & 11.81 \\
\hline & & 37.24 & 62.76 & 34.86 & 65.14 \\
\hline \multirow{3}{*}{$\begin{array}{c}\text { Horizontal } \\
\text { cooperation } \\
\text { in } \mathbf{t}-1 \\
\end{array}$} & & \multicolumn{4}{|c|}{ Horizontal cooperation in $\mathbf{t}$} \\
\hline & Non-cooperation & 95.32 & 4.68 & 95.01 & 4.99 \\
\hline & Cooperation & 47.65 & 52.35 & 45.84 & 54.16 \\
\hline \multirow{3}{*}{$\begin{array}{l}\text { Institutional } \\
\text { cooperation } \\
\text { in } t-1\end{array}$} & & \multicolumn{4}{|c|}{ Institutional cooperation in $\mathbf{t}$} \\
\hline & Non-cooperation & 88.63 & 11.37 & 87.68 & 12.32 \\
\hline & Cooperation & 31.59 & 68.41 & 30.17 & 69.83 \\
\hline
\end{tabular}


Table 5. Marginal effects from dynamic random effects probit model

\begin{tabular}{|c|c|c|c|c|c|c|}
\hline & \multicolumn{3}{|c|}{ Unbalanced panel } & \multicolumn{3}{|c|}{ Balanced panel } \\
\hline & \multirow{2}{*}{$\begin{array}{c}\begin{array}{c}\text { Random } \\
\text { effects probit }\end{array} \\
(1)\end{array}$} & \multicolumn{2}{|c|}{$\begin{array}{l}\text { Wooldridge } \\
\text { correction }\end{array}$} & \multirow{2}{*}{$\begin{array}{c}\text { Random } \\
\text { effects probit } \\
(4)\end{array}$} & \multicolumn{2}{|c|}{$\begin{array}{l}\text { Wooldridge } \\
\text { correction }\end{array}$} \\
\hline & & (2) & (3) & & (5) & (6) \\
\hline Cooperation $_{\mathrm{i}, \mathrm{t}-1}$ (persistence) & $\begin{array}{c}0.473 * * * \\
(0.008)\end{array}$ & $\begin{array}{l}0.337 * * * \\
(0.018)\end{array}$ & $\begin{array}{l}0.318 * * * \\
(0.029)\end{array}$ & $\begin{array}{c}0.470 * * * \\
(0.011)\end{array}$ & $\begin{array}{l}0.329 * * * \\
(0.020)\end{array}$ & $\begin{array}{l}0.311^{* * *} \\
(0.037)\end{array}$ \\
\hline Cooperation $_{\mathrm{i}, \mathrm{t} 0}$ (initial conditions) & & $\begin{array}{c}0.188 * * * \\
(0.021)\end{array}$ & $\begin{array}{c}0.187 * * * \\
(0.021)\end{array}$ & & $\begin{array}{l}0.204 * * * \\
(0.024)\end{array}$ & $\begin{array}{l}0.204 * * * \\
(0.024)\end{array}$ \\
\hline R\&D activities ${ }_{i, t-1}$ & & & $\begin{array}{c}0.076 * * * \\
(0.018)\end{array}$ & & & $\begin{array}{c}0.085 * * * \\
(0.023)\end{array}$ \\
\hline $\mathrm{R} \& \mathrm{D}$ activities $_{\mathrm{i}, \mathrm{t} 0}$ (initial conditions) & & & $\begin{array}{l}0.036^{*} \\
(0.021)\end{array}$ & & & $\begin{array}{c}0.028 \\
(0.033)\end{array}$ \\
\hline Cooperation $_{\mathrm{i}, \mathrm{t}-1} * \mathrm{R}^{\mathrm{N}} \&$ activities $_{\mathrm{i}, \mathrm{t}-1}$ & & & $\begin{array}{c}0.017 \\
(0.027)\end{array}$ & & & $\begin{array}{c}0.016 \\
(0.037)\end{array}$ \\
\hline Incoming spillovers & $\begin{array}{c}0.095 * * * \\
(0.016)\end{array}$ & $\begin{array}{c}0.106 * * * \\
(0.018)\end{array}$ & $\begin{array}{c}0.090 * * * \\
(0.018)\end{array}$ & $\begin{array}{c}0.090 * * * \\
(0.020)\end{array}$ & $\begin{array}{c}0.099 * * * \\
(0.024)\end{array}$ & $\begin{array}{c}0.086 * * * \\
(0.024)\end{array}$ \\
\hline Legal (IP) protection & $\begin{array}{c}0.035 * * * \\
(0.009)\end{array}$ & $\begin{array}{c}0.040 * * * \\
(0.010)\end{array}$ & $\begin{array}{c}0.036 * * * \\
(0.010)\end{array}$ & $\begin{array}{c}0.036 * * * \\
(0.011)\end{array}$ & $\begin{array}{c}0.041 * * * \\
(0.013)\end{array}$ & $\begin{array}{c}0.037 * * * \\
(0.013)\end{array}$ \\
\hline $\mathrm{R} \& \mathrm{D}$ intensity & $\begin{array}{c}0.088 * * * \\
(0.024)\end{array}$ & $\begin{array}{c}0.107 * * * \\
(0.028)\end{array}$ & $\begin{array}{c}0.092 * * * \\
(0.028)\end{array}$ & $\begin{array}{c}0.096 * * * \\
(0.035)\end{array}$ & $\begin{array}{c}0.123 * * * \\
(0.042)\end{array}$ & $\begin{array}{c}0.110 * * * \\
(0.042)\end{array}$ \\
\hline Firm size (base <50 employees) & & & & & & \\
\hline $50-249$ emp & $\begin{array}{c}0.039 * * * \\
(0.010)\end{array}$ & $\begin{array}{c}0.046 * * * \\
(0.012)\end{array}$ & $\begin{array}{c}0.045 * * * \\
(0.012)\end{array}$ & $\begin{array}{c}0.038 * * * \\
(0.013)\end{array}$ & $\begin{array}{c}0.047 * * * \\
(0.016)\end{array}$ & $\begin{array}{c}0.045 * * * \\
(0.016)\end{array}$ \\
\hline $250-499 \mathrm{emp}$ & $\begin{array}{c}0.056 * * * \\
(0.016)\end{array}$ & $\begin{array}{c}0.067 * * * \\
(0.020)\end{array}$ & $\begin{array}{c}0.075 * * * \\
(0.020)\end{array}$ & $\begin{array}{c}0.056 * * * \\
(0.020)\end{array}$ & $\begin{array}{c}0.070 * * * \\
(0.025)\end{array}$ & $\begin{array}{c}0.075 * * * \\
(0.025)\end{array}$ \\
\hline 500 or more emp & $\begin{array}{c}0.102 * * * \\
(0.018)\end{array}$ & $\begin{array}{c}0.119 * * * \\
(0.022)\end{array}$ & $\begin{array}{c}0.126 * * * \\
(0.022)\end{array}$ & $\begin{array}{c}0.097 * * * \\
(0.023)\end{array}$ & $\begin{array}{c}0.115 * * * \\
(0.028)\end{array}$ & $\begin{array}{c}0.118 * * * \\
(0.029)\end{array}$ \\
\hline Public funding for innovation & & & & & & \\
\hline Local funding & $\begin{array}{c}0.096 * * * \\
(0.010)\end{array}$ & $\begin{array}{c}0.099 * * * \\
(0.011)\end{array}$ & $\begin{array}{c}0.092 * * * \\
(0.011)\end{array}$ & $\begin{array}{c}0.103 * * * \\
(0.013)\end{array}$ & $\begin{array}{c}0.103 * * * \\
(0.015)\end{array}$ & $\begin{array}{c}0.097 * * * \\
(0.015)\end{array}$ \\
\hline National funding & $\begin{array}{c}0.099 * * * \\
(0.011)\end{array}$ & $\begin{array}{c}0.104 * * * \\
(0.012)\end{array}$ & $\begin{array}{c}0.096 * * * \\
(0.012)\end{array}$ & $\begin{array}{c}0.098 * * * \\
(0.013)\end{array}$ & $\begin{array}{c}0.101 * * * \\
(0.015)\end{array}$ & $\begin{array}{c}0.094 * * * \\
(0.015)\end{array}$ \\
\hline European funding & $\begin{array}{c}0.119 * * * \\
(0.019)\end{array}$ & $\begin{array}{c}0.124 * * * \\
(0.022)\end{array}$ & $\begin{array}{c}0.121 * * * \\
(0.022)\end{array}$ & $\begin{array}{c}0.133 * * * \\
(0.023)\end{array}$ & $\begin{array}{c}0.134 * * * \\
(0.027)\end{array}$ & $\begin{array}{c}0.132 * * * \\
(0.027)\end{array}$ \\
\hline Belongs to a group & $\begin{array}{c}0.062 * * * \\
(0.010)\end{array}$ & $\begin{array}{c}0.071 * * * \\
(0.012)\end{array}$ & $\begin{array}{c}0.071 * * * \\
(0.012)\end{array}$ & $\begin{array}{c}0.077 * * * \\
(0.013)\end{array}$ & $\begin{array}{c}0.091 * * * \\
(0.015)\end{array}$ & $\begin{array}{c}0.090 * * * \\
(0.015)\end{array}$ \\
\hline Industry dummy variables & Included & Included & Included & Included & Included & Included \\
\hline Time dummy variables & Included & Included & Included & Included & Included & Included \\
\hline Observations & 17,568 & 17,568 & 17,568 & 12,012 & 12,012 & 12,012 \\
\hline Number of firms & 7,566 & 7,566 & 7,566 & 4,004 & 4,004 & 4,004 \\
\hline $\log \mathrm{L}$ & -8418.381 & -8370.928 & -8393.193 & -5852.373 & -5809.207 & -5795.298 \\
\hline Wald test $\left(\chi^{2}\right)$ & 5007.341 & 3605.362 & 5011.80 & 3256.116 & 2339.050 & 2349.590 \\
\hline & Pval $=0.000$ & Pval $=0.000$ & Pval $=0.000$ & Pval $=0.000$ & Pval $=0.000$ & Pval $=0.000$ \\
\hline$\sigma_{\alpha}$ & $\begin{array}{c}0.226 \\
(0.057)\end{array}$ & $\begin{array}{c}0.635 \\
(0.046)\end{array}$ & $\begin{array}{c}0.233 \\
(0.056)\end{array}$ & $\begin{array}{c}0.294 \\
(0.059)\end{array}$ & $\begin{array}{c}0.686 \\
(0.051)\end{array}$ & $\begin{array}{c}0.687 \\
(0.051)\end{array}$ \\
\hline Rho $(\rho)$ & $\begin{array}{c}0.049 \\
(0.023)\end{array}$ & $\begin{array}{c}0.288 \\
(0.030)\end{array}$ & $\begin{array}{c}0.051 \\
(0.024)\end{array}$ & $\begin{array}{c}0.080 \\
(0.029)\end{array}$ & $\begin{array}{c}0.320 \\
(0.032)\end{array}$ & $\begin{array}{c}0.321 \\
(0.032)\end{array}$ \\
\hline Likelihood test $\left(H_{0}: \rho=0\right)$ & $\begin{array}{c}4.375 \\
\text { Pval }=0.018\end{array}$ & $\begin{array}{c}78.444 \\
\text { Pval }=0.000\end{array}$ & $\begin{array}{c}4.825 \\
\text { Pval }=0.014\end{array}$ & $\begin{array}{c}7.681 \\
\text { Pval }=0.003\end{array}$ & $\begin{array}{c}77.860 \\
\text { Pval }=0.000\end{array}$ & $\begin{array}{c}78.135 \\
\text { Pval }=0.000\end{array}$ \\
\hline
\end{tabular}

Standard errors in parentheses. $* * * \mathrm{p}<0.01, * * \mathrm{p}<0.05, * \mathrm{p}<0.1$

Note: The marginal effects are calculated as the average partial effects. The use of lagged explanatory variables reduces the number of observations with respect to Table 1 . 
Table 6. Marginal effects from dynamic random effects probit model (unbalanced panel)

Cooperation $_{\mathrm{i}, \mathrm{t}-1}$

Cooperation $_{\mathrm{i}, \mathrm{t}-2}$

Coop $_{i, t-2 / t-1=0}$

Cooperation $_{\mathrm{i}, \mathrm{t} 0}$

Incoming spillovers

Legal (IP) protection

R\&D intensity

Firm size (base <50 employees)

50 - 249 emp

$250-499 \mathrm{emp}$

500 or more emp

Public funding for innovation

Local funding

National funding

European funding

Belongs to a group

Industry dummy variables

Time dummy variables (base

Time2006)

Time2008

Time2010

Observations

Number of firms

$\log \mathrm{L}$

Wald test $\left(\chi^{2}\right)$

$\sigma_{\alpha}$

Rho $(\rho)$

Likelihood test $\left(H_{0}: \rho=0\right)$
Random effects probit

Wooldridge correction

\begin{tabular}{cc}
\hline$(1)$ & $(2)$ \\
\hline $0.483 * * *$ & $0.482 * * *$ \\
$(0.011)$ & $(0.011)$ \\
$0.138^{* * *}$ & $0.121 * * *$ \\
$(0.014)$ & $(0.020)$
\end{tabular}

Random Wooldridge effects probit correction

Wooldridge correction

(3) (4)

\begin{tabular}{cc}
\multicolumn{2}{c}{ Wooldridge correction } \\
Manufacturing & Service \\
firms & Firms \\
\hline$(5)$ & $(6)$ \\
\hline $0.323^{* * *}$ & $0.360 * * *$ \\
$(0.022)$ & $(0.029)$
\end{tabular}

$0.082 * * * \quad 0.057 * * *$

(0.012)

(0.021)

0.022

(0.018)

$0.106 * * *$

$0.106 * * *$

(0.022)

$0.050 * * *$

(0.022)

(0.013)

$0.050 * * *$

0.048

(0.013)

(0.035)

0.047

(0.035)

$0.041 * * *$

$0.041 * * *$

(0.014)

$0.065 * * *$

(0.014)

(0.022)

$0.109 * * *$

$0.065 * * *$

(0.022)

(0.024)

$0.109 * * *$

(0.024)

0.026

$(0.017)$

$0.030 *$

$0.030^{*}$

(0.016)

$0.033 * * *$

(0.016)

(0.010)

$0.034 * * *$

(0.010)

0.012

0.012

(0.033)

(0.033)

$0.025 * *$

$0.025^{* *}$

(0.011)

$0.040 * *$

(0.011)

$0.041 * *$

(0.019)

$0.075^{* * *}$

(0.019)

(0.023)

$0.076^{* * * *}$

(0.024)

$0.051 * * *$

$0.050 * * *$

(0.012)

(0.013)

(0.014)

$0.101^{* *}$

$0.099 * * *$

$0.099 * * *$

$(0.015)$

(0.015)

$0.079 * * *$

$0.079 * * *$

0.066 ***

$0.067 * * *$

(0.014)

(0.014)

0.051

(0.031)

(0.032)

$0.042 * * *$

0.013

0.013

$0.042 * * *$

(0.013)

(0.010)

(0.010)

Included Included

Included

Included

$\begin{array}{cc}0.183 * * * & 0.189 * * * \\ (0.025) & (0.039) \\ 0.103 * * * & 0.104 * * * \\ (0.021) & (0.033) \\ 0.025 * * & 0.069 * * * \\ (0.012) & (0.020) \\ 0.285 * * * & 0.058 * \\ (0.066) & (0.033) \\ & \\ 0.056 * * * & 0.027 \\ (0.014) & (0.024) \\ 0.096 * * * & 0.012 \\ (0.025) & (0.033) \\ 0.126 * * * & 0.107 * * * \\ (0.030) & (0.033) \\ & \\ 0.092 * * * & 0.109 * * * \\ (0.013) & (0.022) \\ 0.090 * * * & 0.120 * * * \\ (0.014) & (0.022) \\ 0.114 * * * & 0.140 * * * \\ (0.029) & (0.032) \\ 0.083 * * * & 0.042 * * \\ (0.014) & (0.021) \\ \end{array}$

Included

Included

\begin{tabular}{|c|c|c|c|c|c|}
\hline Included & Included & Included & Included & $\begin{array}{c}-0.038 * * * \\
(0.012)\end{array}$ & $\begin{array}{c}-0.001 \\
(0.020)\end{array}$ \\
\hline ncluded & Included & Included & Included & $\begin{array}{c}-0.031 * * \\
(0.012)\end{array}$ & $\begin{array}{l}0.013 \\
(0.21)\end{array}$ \\
\hline 10,002 & 10,002 & 6,104 & 6,104 & 11,727 & 5,841 \\
\hline 5,998 & 5,998 & 4,133 & 4,133 & 4,873 & 2,693 \\
\hline 4441.680 & -4440.926 & -2369.920 & -2368.611 & -5557.141 & -2799.234 \\
\hline 2438.253 & 2438.502 & 298.691 & 125.828 & 2262.29 & 1292.96 \\
\hline $\mathrm{al}=0.000$ & Pval $=0.000$ & Pval $=0.000$ & Pval $=0.000$ & Pval $=0.000$ & Pval $=0.000$ \\
\hline 0.267 & 0.268 & 0.010 & 0.294 & 0.646 & 0.616 \\
\hline$(0.082)$ & $(0.067)$ & $(0.044)$ & $(0.371)$ & $(0.056)$ & $(0.081)$ \\
\hline 0.066 & 0.067 & 0.001 & 0.080 & 0.294 & 0.275 \\
\hline$(0.038)$ & $(0.038)$ & $(0.009)$ & $(0.185)$ & $(0.036)$ & $(0.052)$ \\
\hline 2.995 & 3.008 & 0.001 & 0.173 & 55.28 & 23.61 \\
\hline $\mathrm{al}=0.042$ & Pval $=0.041$ & Pval $=0.491$ & Pval $=0.339$ & Pval $=0.000$ & Pval $=0.000$ \\
\hline
\end{tabular}

Standard errors in parentheses. $* * * p<0.01, * * p<0.05, * p<0.1$

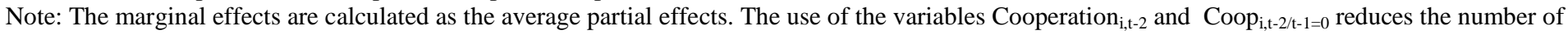
observations with respect to Table 5 . 
Table 7. Marginal effects from multivariate dynamic random effects probit model - Type of cooperation (unbalanced panel)

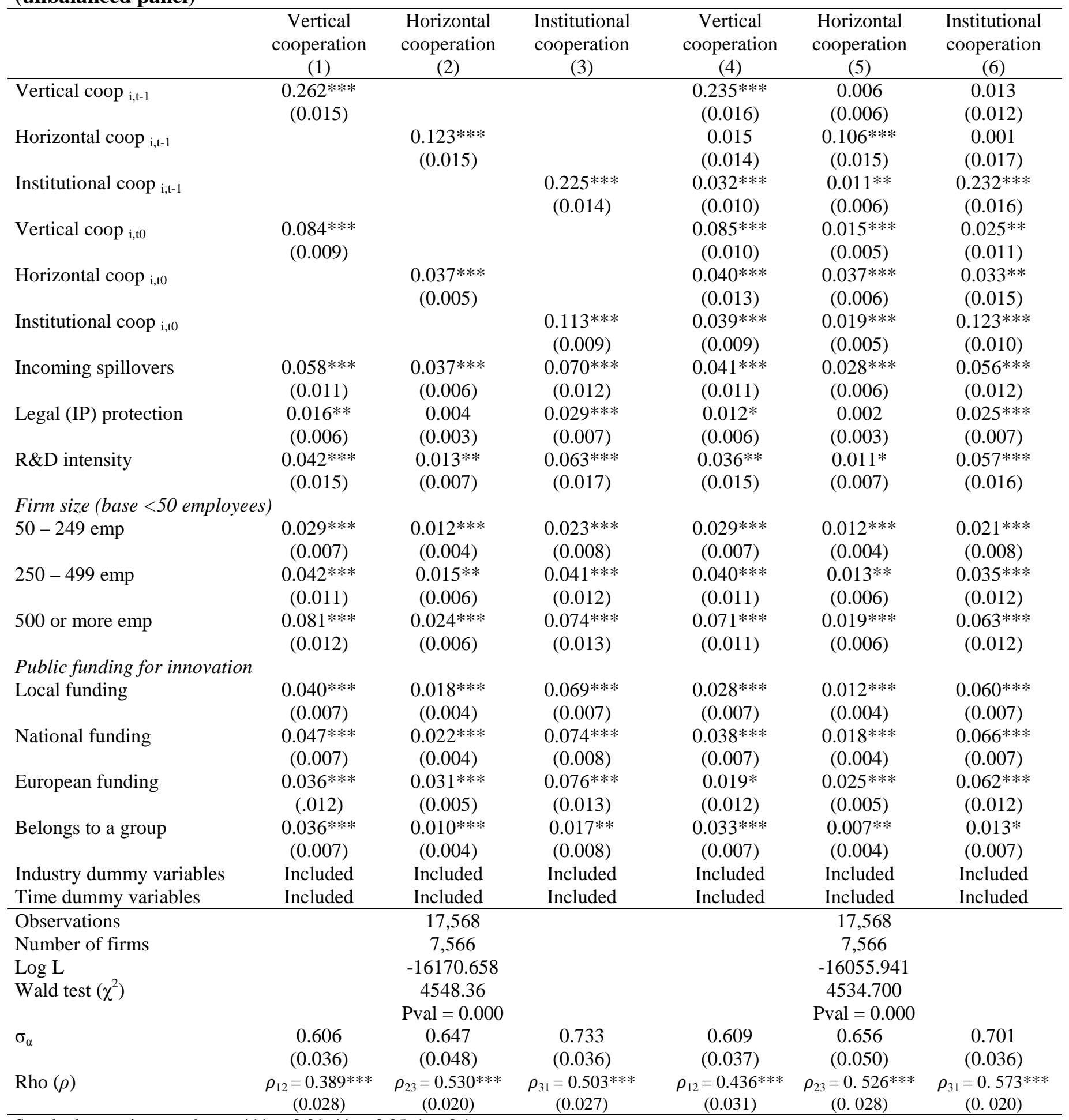

Standard errors in parentheses. $* * * \mathrm{p}<0.01, * * \mathrm{p}<0.05, * \mathrm{p}<0.1$

Note: The marginal effects are calculated as the average partial effects. 


\section{Appendix}

Table A1. Definition of the variables included in the empirical analysis

\begin{tabular}{|c|c|}
\hline Variables & Definitions \\
\hline \multicolumn{2}{|l|}{ Dependent } \\
\hline Cooperation $_{\mathrm{t}}$ & $\begin{array}{l}=1 \text { if the firm cooperated in some of its innovation activities with other enterprises or institutions in the } \\
\text { period } t \\
=0 \text { otherwise }\end{array}$ \\
\hline \multicolumn{2}{|l|}{ Type of Cooperation: } \\
\hline Vertical Cooperation $_{t}$ & $\begin{array}{l}=1 \text { if the firm cooperated in some of its innovation activities with clients or customers; or with suppliers } \\
\text { of equipment, materials, components, or software in the period t } \\
=0 \text { otherwise }\end{array}$ \\
\hline Horizontal Cooperation $_{\mathrm{t}}$ & $\begin{array}{l}=1 \text { if the firm cooperated in some of its innovation activities with competitors or other enterprises in the } \\
\text { same sector in the period } t \\
=0 \text { otherwise }\end{array}$ \\
\hline Institutional Cooperation $_{\mathrm{t}}$ & $\begin{array}{l}=1 \text { if the firm cooperated in some of its innovation activities with consultants, commercial labs or } \\
\text { private } R \& D \text { institutes; universities or other higher education institutions; government or public research } \\
\text { institutes; technological centres in the period t } \\
=0 \text { otherwise }\end{array}$ \\
\hline \multicolumn{2}{|l|}{ Independent } \\
\hline Cooperation $_{\mathrm{t}-1}$ & $\begin{array}{l}=1 \text { if the firm cooperated in some of its innovation activities with other enterprises or institutions in the } \\
\text { period } t-1 \\
=0 \text { otherwise }\end{array}$ \\
\hline Incoming spillovers & $\begin{array}{l}=1 \text { if the firm gives high importance to the following information sources for undertaking its innovation } \\
\text { activities: conferences, trade fairs, exhibitions; scientific journals, or trade/technical publications; } \\
\text { professional or industry associations. } \\
=0 \text { otherwise }\end{array}$ \\
\hline Legal (IP) Protection & $\begin{array}{l}\text { = } 1 \text { if the firm uses at least one of the following legal IP methods for protecting inventions or } \\
\text { innovations: applied for a patent; registered an industrial design; registered a trademark; claimed a } \\
\text { copyright } \\
=0 \text { otherwise }\end{array}$ \\
\hline R\&D Intensity & Ratio of intramural R\&D expenditure to sales turnover \\
\hline Firm Size & $\begin{array}{ll}<50 \text { employees } & =1 \text { if the firm has less than } 50 \text { employees; }=0 \text { otherwise } \\
50-249 \text { employees } & =1 \text { if the firm has between } 50 \text { and } 249 \text { employees } ;=0 \text { otherwise } \\
250-499 \text { employees } & =1 \text { if the firm has between } 250 \text { and } 499 \text { employees } ;=0 \text { otherwise } \\
500 \text { or more employees } & =1 \text { if the firm has } 500 \text { or more employees; }=0 \text { otherwise }\end{array}$ \\
\hline Local funding & $\begin{array}{l}=1 \text { if the firm receives funding from local or regional authorities to carry out its innovation activities } \\
=0 \text { otherwise }\end{array}$ \\
\hline National funding & $\begin{array}{l}=1 \text { if the firm receives funding from central government to carry out its innovation activities } \\
=0 \text { otherwise }\end{array}$ \\
\hline European funding & $\begin{array}{l}=1 \text { if the firm receives funding from European Union to carry out its innovation activities } \\
=0 \text { otherwise }\end{array}$ \\
\hline Belongs to a group & $\begin{array}{l}=1 \text { if the firm belongs to a group of enterprises } \\
=0 \text { otherwise }\end{array}$ \\
\hline
\end{tabular}

Table A2. Correlation between the explanatory variables and their corresponding within means

\begin{tabular}{ll}
\hline Incoming spillovers & 0.839 \\
Legal (IP) protection & 0.832 \\
R\&D intensity & 0.941 \\
Firm size & 0.981 \\
Local funding & 0.836 \\
National funding & 0.826 \\
European funding & 0.846 \\
Belonging to a group & 0.954 \\
\hline
\end{tabular}

